\title{
Mixing Local and Regional, Traditional and Non-traditional Elements: the Case of the Graduale Wladislai
}

\author{
Gábor Kiss / gabork@zti.hu
}

Research Centre for the Humanities of the Hungarian Academy of Sciences, Institute of Musicology, Budapest, HU

\begin{abstract}
In the late medieval manuscript heritage of Central Europe we encounter sources that cannot easily be classified according to liturgical traditions. For an approach regarding the traditions as a value, these atypical late sources may give the impression of decline and corruption. However, these sources can show well what kind of connections might have existed between the traditions. How wide could have been the compilators' horizon? Which traditional melodies, variants or tradition independent popular pieces became known to them? What tendencies, transmission lines and cultural channels can we observe in the melody history of the region, etc.? So, from the point of view of cultural history the detailed analysis of such sources can be just as interesting as the experiences of a comparative research of the traditions.

One of the most interesting such manuscripts is the richly decorated monumental Graduale Wladislai. The literature connects it to Wladislaus the 2nd (Hungarian and Bohemian king), but there is no convincing explanation for what purpose the poor king would have ordered such a representative codex of ambigous content. In all probability it was manufactured in a Bohemian scriptory and as a whole the manuscript is alien to the Hungarian tradition. However, its content is less Bohemian than the outer appearance suggests and some Hungarian charactersitics were also included in the repertory. Apparently several codices of different traditions were used as models and they were combined in a creative way. This paper rather concentrates on the layer of the special, tradition independent or ambigous chants of the manuscript that either represent individual initiatives or might represent the influences of several traditions.
\end{abstract}

\section{Key words}

Mass repertory, Graduale, Notation, Chant tradition, Wladislaus II, Alleluia, Esztergom 
In the late medieval manuscript heritage of Central Europe it is not rare to encounter sources that cannot easily be classified according to liturgical traditions. Being produced under special circumstancies or for special purposes they sometimes show a kind of independence from the system of traditions and suggest a super regional character. For an approach regarding the traditions as a value, these atypical 15th-16th century sources may give the impression of decline and corruption. However, another approach is possible. These sources can show well what kind of connections might have existed between the traditions. How wide could have been the compilators' horizon? Which traditional melodies, variants or tradition independent popular pieces became known to them? What tendencies, transmission lines and cultural channels can we observe in the melody history of the region? So, from the point of view of cultural history the detailed analysis of such sources can be just as interesting as the experiences of a comparative research of the traditions.

One of the most interesting such manuscripts is the richly decorated and illuminated monumental Graduale Wladislai. ${ }^{1}$ The literature connects it to Wladislaus the 2nd (Hungarian and Bohemian king, member of the Polish Jagello family), ${ }^{2}$ but there is no convincing explanation when and for what purpose the poor king would have ordered such a representative codex of ambigous content. In all probability it was manufactured in a Bohemian scriptory (as the miniatures and notation show) and based on a comparison with other manuscripts (e.g. the graduals from Mlada Boleslav, Kuttenberg, the cantionale Franus, the Jena-codex, and last but not least the graduale Waradiense ${ }^{3}$ ) the manuscript must have been illuminated by Joannes Zmilely de Pisek or one of his followers. ${ }^{4}$ Moreover, the manuscript as a whole, including its content, repertory and melodic variants is alien to the Hungarian tradition. ${ }^{5}$ However, its content is less Bohemian than the outer appearance suggests: the representation of Bohemian saints are relatively modest: the Sanctorale does not contain either the feasts of Adalbert, Sigismundus, Procopius or that of the Quinque Fratrum. ${ }^{6}$ The only Bohemian saints included are St. Ludmilla and St. Wencel but both without proper items. ${ }^{7}$ While all Bohemian and some of the Polish graduals give for Wencel a proper alleluia (Consolator miserorum), (Tab. 1)

1 H-Efkö Mss. I. 3.

2 CSONTOSI, János. Könyvkiállítási emlék. Budapest: Országos Magyar Iparmúvészeti Múzeum, 1882, 112: No. 324. BERKOVITS, Ilona. Az esztergomi Ulászló-graduale. Magyar Könyuszemle, 1941, vol. 65, pp. 342-353.

3 Mladá Boleslav, Muzeum Mladaboleslavska, 21691 (CZ-MBm 21691); Wien, Österreichische Nationalbibliothek Mus. Hs. 15501 (A-Wn Mus. Hs. 15501); Hradec Králové, Muzeum Východních Čech, II A 6 (CZ-HKm II A 6); Praha, Knihovna Národního muzea, IV.B.24; Győr, Egyházmegyei Kincstár és Könyvtár (Diocesan Treasury and Library), s. n.

4 BERKOVITS, op. cit., p. 349; RADÓ, D. Polycarpus OSB. Libri liturgici manuscripti bibliothecarum Hungariae et limitropharum regionum. Budapest: Akadémiai Kiadó, 1973, p. 513.

5 SZENDREI, Janka. A magyar középkor hangjegyes forrásai [Notated Manuscripts of the Hungarian Middle Ages]. Budapest: MTA Zenetudományi intézet, 1981, pp. 41-42.

6 KISS, Gábor. Az Ulászló-graduále utóélete az újabb kutatások fényében [The Later History of the Graduale Wladislai in the Light of Recent Studies]. Magyar Egyházzene, 2013, vol. 20, pp. 315-322.

7 F. H. Graham mistakenly stated that the two feasts had proper ,antiphons”, see GRAHAM, Barry Frederic Hunter. Bohemian and Moravian Graduals 1420-1620. Turnhout: Brepols, 2006, p. 162. 
the Graduale Wladislai only celebrates him with common material. While the presence of Ludmilla is not without interest, the appearance of Wenceslaus is of no significance: we find it with common material in true Hungarian manuscripts as well. The only common melody of this set that connects our gradual to Bohemian sources is the offertory Posuisti Domine, which we never find at this point in the Hungarian tradition. ${ }^{8}$ Finally, the Prosary contains the proper sequence generally assigned for the feast of St. Wencel in Czech sources (Christe tui praeclari), which is otherwise a contrafact of the sequence for Omnium Sanctorum (Omnes sancti Seraphim). ${ }^{9}$

\begin{tabular}{|c|c|c|c|c|c|}
\hline & PL-WRu B 1714 & CZ-Pu XII A 21 & H-Bn 172b & H-Efkö Mss. 3b & H-Efkö Mss. I. 3. \\
\hline Intr & In virtute tua* & In virtute tua* & In virtute tua* & In virtute tua* & In virtute tua* \\
\hline $\mathrm{Gr}$ & Domine praevenisti* & $\begin{array}{l}\text { Domine } \\
\text { praevenisti* }\end{array}$ & Posuisti Domine* & $\begin{array}{l}\text { Justus non } \\
\text { conturbabitur* }\end{array}$ & - \\
\hline All & Consolator miserorum & $\begin{array}{l}\text { Consolator } \\
\text { miserorum }\end{array}$ & Justus germinabit* & Justus germinabit* & Laetabitur justus* \\
\hline Off & Posuisti Domine* & Posuisti Domine* & In virtute tua * & In virtute tua * & Posuisti Domine* \\
\hline Comm & Magna est gloria* & Magna est gloria* & Posuisti Domine* & Qui vult venire* & Magna est gloria* \\
\hline
\end{tabular}

Tab. 1. Masses for St. Wenceslaus

In contrast with the Bohemian or Central European characteristics we find some definitely Hungarian components (or references to the Hungarian practice) in the manuscripts that would be quite unusual in a Bohemian gradual. For example, in the litany for Holy Saturday also the Hungarian saints (Adalbertus, Gerhardus, Stephanus, Henricus, Ladislaus) are listed (Facsimile 1). Furthermore, although the Sanctorale is lacking Hungarian saints, in the Prosary we find proper alleluias and sequences for St. Stephen and St. Emeric (all. Quem caelestis armonia, sequ. all. Ave flos nobilium, sequ. Stirps regalis). Because of the described ambiguity, Polikárp Radó, the first codicologist describing the manuscript, believed that it was modelled on a Bohemian source but was copied in Hungary making it possible to include the Hungarian components. ${ }^{10}$ According to later scholars, however, it must have been produced in a Prague scriptory, but based on several models, including Hungarian ones. ${ }^{11}$ At the same time, the situation is more complex than the manuscript simply being the work of a compiler who combined more models or mechanically amalgamated them by selecting one component from one model while picking others from elsewhere. The final product shows a kind of creative attitude to the

8 But this could be also misleading for this common offertory is used in Polish, Moravian and other regional sources as well.

9 H-Efkö Mss. I. 3, f 344. It can also be found in another "peripheral" Hungarian manuscript, namely the gradual from Spiš (SK-Sk Ms. Mus. No. 1, f 192), which in other respects show foreign charactersitics.

10 RADÓ, op. cit., p. 513.

11 See e.g. KÖRMENDY, Kinga. Ulászló-graduále: kérdések és lehetséges válaszok [The Ladislaus Gradual: Questions and Possible Explanations]. Ars Hungarica, 2013, vol. 39, no. 1, pp. 114-122; KISS, op. cit., p. 318. 
Mixing Local and Regional, Traditional and Non-traditional Elements...

task resulting in a number of unique or at least hardly definable pieces. This leaves even much more room for speculation about the commissioner, the commissioner's motivation, and the targeted function of the book (i.e. the practical question of where and in what way it was intended to be used).

Let's see some examples of the creative solutions that cannot easily be interpreted along one or the other, more or less consistent tradition. Although we find four pieces attributed to Hungarian saints, only one of them, namely the sequence Corde voce mente pura is completely identical with its equivalent in the Hungarian sources. In case of the alleluia Ave flos nobilium (Ex. 1a) for St. Emeric only the textual component is of Hungarian origin (it is probably a 13th century Hungarian composition for the Magnificat antiphon of the St. Emeric office). As an alleluia it was never used in Hungary, although the present melody was not unknown: it is a borrowing from the alleluia $O$ Maria rubens rosa (Ex. 1b), very popular in the Central European region (South-Germany, Bohemia, Poland and Hungary too). The text-melody combination of the Graduale Wladislai is unique, no other example of it has been found so far.

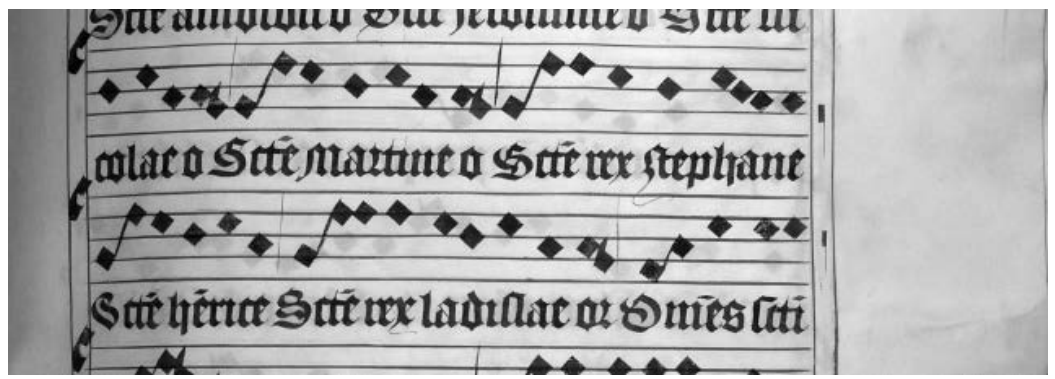

Facsimile 1. H-Efkö Mss. I. 3, f. 128.

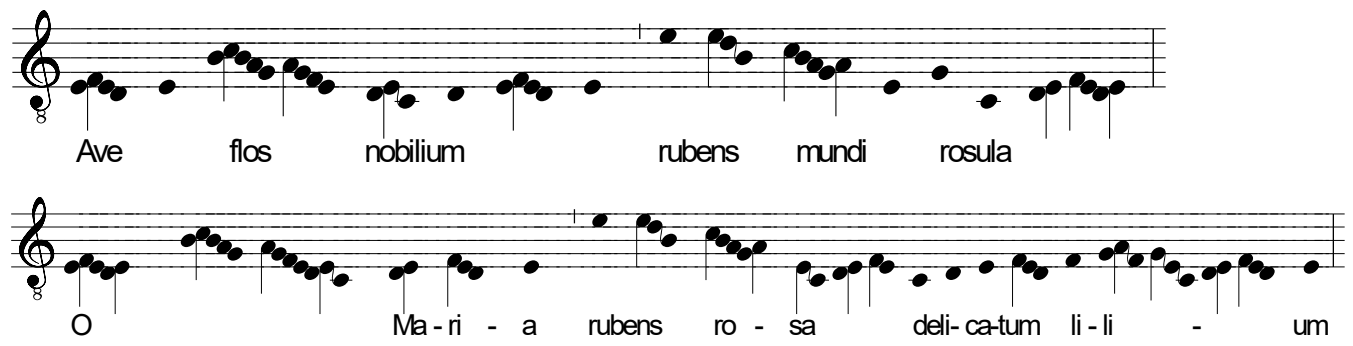

Ex. 1a/b. All. Ave flos nobilium, O Maria rubens rosa; H-Efkö Mss. I. 3, ff 340v, 251.

The sequence for St. Emeric is a Hungarian composition (even Analecta Hymnica knows it only from Hungary ${ }^{12}$ ), it was very popular there (except for Transylvania) and was

12 DREVES, Guido Maria (ed.). Analecta Hymnica Medii Aevi, vol. 9. Leipzig: O. R. Reisland, 1890, no. 195. 
always sung on a D-mode melody (Ex. 2a). Since the compiler of the Graduale Wladislai should have Hungarian models at his disposal (several observations suggest it), it is quite surprising that he replaced the Hungarian D-mode melody with an E-mode one, unknown sofar (Ex. 2b).
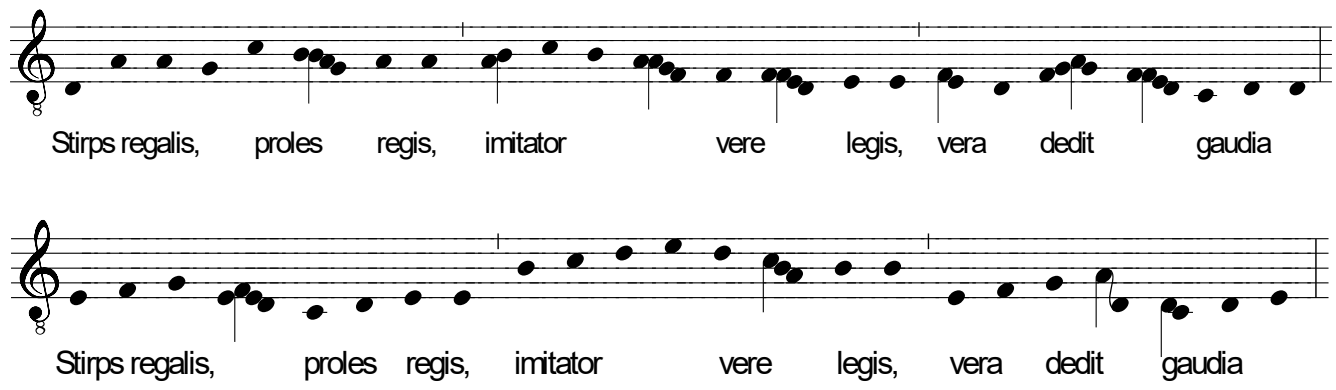

Ex. 2a/b. Sequ. Stirps regalis; H-Efkö Mss. 3b, f 227, H-Efkö Mss. I. 3, f 341.
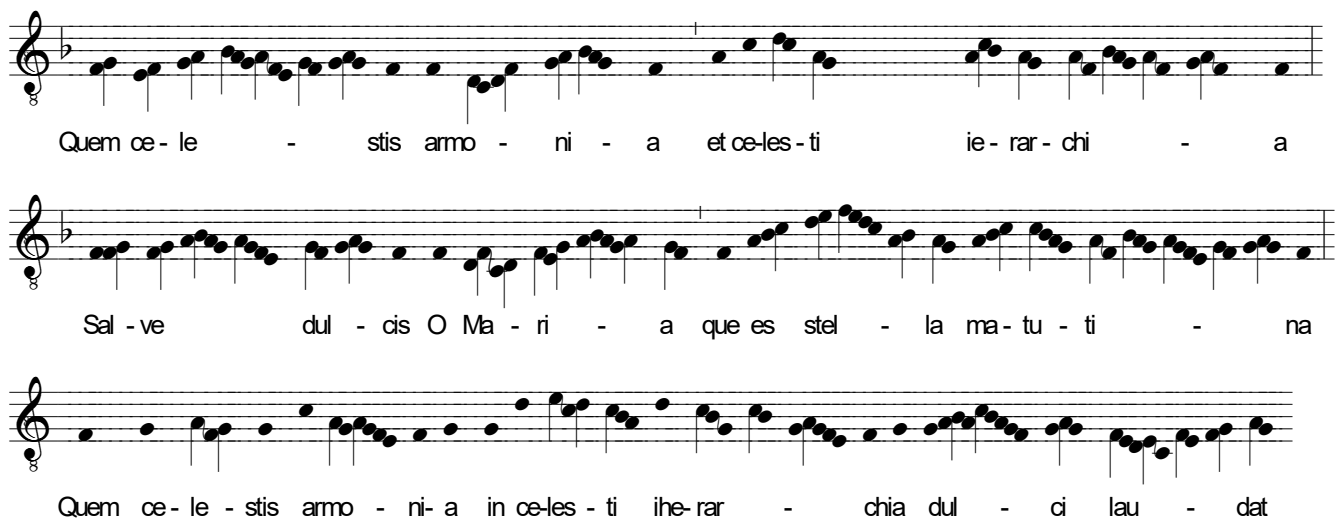

Ex. 3a. All. Quem caelestis armonia, H-Efkö Mss. I. 3, f 338; 3b. All. Salve dulcis O Maria, A-SCH Cpl. 2., f 164v; 3c. All. Quem caelestis armonia, PL-Wn s. n., f 299v.

An even more misterious case is the alleluia for St. Stephen (Ex. 3a). The piece can also be found in Karlheinz Schlager's Alleluia-edition, which includes the Graduale Wladislai as a Bohemian source. ${ }^{13}$ Although the chant appears in the edition as an independent alleluia, the unique text is actually combined with an existing melody, very polular in the wider region. Mostly it was known with the text Salve dulcis o Maria (Ex. 3b), but being a popular melody it was used with other texts as well. Although the text of the gradual refers directly to King Stephen, the content of the whole seems rather general

13 SCHLAGER, Karlheinz. Alleluia-Melodien. Kassel-Basel: Bärenreiter, 1987, pp. 413, 756. As it turns out from the foregoing, the "Bohemian" definition is a simplification. It is even more problematic, however, that no other source related to medieval Hungary was included in the edition. 
and unspecific. For that very reason, Janka Szendrei assumed that the text must have had antecedents, and must be searched primarily among Bohemian sources. ${ }^{14}$ During the 25 years after her desideratum a great number of Bohemian sources have been examined, yet, not any version of the text has been found. Recently, however, I have found it in a Polish manuscript, a 15th-century Benedictine gradual from Tyniec. ${ }^{15}$ Bartosz Izbiczki assumed that the piece may have been a Tyniec local composition. ${ }^{16}$ Both sources have the same text, the slight differences are the consequences of their different assignment. In contrast with the Graduale Wladislai the Polish source applies the piece for the feast of St. Benedict (Ex. 3c). Any direct connection of the sources seems not possible: the alleluia from Tyniec uses a different melody, moreover its text variant also seems to be a secondary adaptation (see the insertion of the word "Benedictum") (Ex. 4).

De sancto Stephano

Quem celestis armonia et celesti ierarchia dulci laudat simphonia.
De sancto Benedicto

Quem celestis armonia

in celesti ierarchia

dulci laudat Benedictum Simphonia.

Ex. 4. Alleluia from Tyniec.

In any case, we learn from this case that in the evaluation of the content of the graduale Wladislai we have to extend the research to areas other than Bohemia, for example to Polish sources. Another example of a possible Polish influence is the alleluia Margaretha que decreta. According to Schlager's edition (which used a great many Bohemian sources) this can be documented only from the Graduale Wladislai. ${ }^{17}$ At the same time, according to the Polish literature it was known in Poland and can be found in several sources from Wrocław and in numerous Polish Premonstratensian manuscripts. ${ }^{18}$

A puzzling set of pieces can be read before the beginning of the main part of the codex. These chants raise again the questions of orientation of the compiler or commissioner. On $\mathrm{f} 7 \mathrm{v}$ we see an antiphon and a trope (Melchisedech rex Salem - Rex Christe primogenite) (Facsimile 2-3). According to Hana Wlhová-Wörner they belong to the utraquist repertory of the Corpus Christi votive Mass (during Lent). ${ }^{19}$ Really, we don't know the

14 SZENDREI, Janka. A Szent István alleluják dallamai [The melodies of the alleluias for St. Stephen]. Zenetudományi Dolgozatok, 1989, fn. 53.

15 Warsawa, Biblioteka Narodowa, s. n.

16 IZBICZKI, Bartosz. Graduat tyniecki ms. b. s. I w świetle tradycji europejskiej i polskiej. Warsawa: Uniwersytet Kardynała Stefana Wyszyńskiego, 2006. (PhD diss.), pp. 109-110, 191, 255.

17 SCHLAGER, op. cit., pp. 264, 684.

18 PIKULIK, Jerzy. Spiewy Alleluia de Sanctis w polskich rekopisach przedtrydenckich: Studium muzykologiczne. Warsawa: Wydawnictwa Akademii Teologii Katolickiej, 1995, pp. 172-173.

19 VLHOVÁ-WÖRNER, Hana. Bohemian Utraquists‘ Repertory of Proper Tropes. In: The Bohemian Refor- 
chant from elsewhere (a similar text for Corpus Christi exists in Braga, but as a Magnificat antiphon), and we find it in the Graduale from Kutná Horá or Cantionale Franus (both are further examples of utraquists mass books). ${ }^{20}$ Whether the presence of it has something to do with the utraquist milieu where the manuscript was manufactured, and whether it was a conscious decision or not, we don't know. In any case, in the gradual from Mlada Boleslav ${ }^{21}$ we don't find the piece at all, whereas it is part of the actual Mass for Corpus Christi in the Ms. 45 gradual from Cracov. ${ }^{22}$ Moreover, in Cracov the whole mass cycle could be similar to that of the Graduale Wladislai. For example, while the two sources have the same melody for the offertory Sacerdotes incensum, both the Strigonian sources and Cantionale Franus use a different one. Otherwise, the "utraquist" piece appears among traditional chants (with a catholic Credo among them) and the question remains, what would have been the reason for inserting it in a manuscript intended for a true catholic king.

There are several modern alleluias in the manuscript that may point to Bohemian models but not exclusively for they were in use elsewhere too. For example: 1) According to Schlager's edition alleluia Tumba sancti Nicolai and alleluia Rutilantes rosas rosa (Dorothea) can only be found in a few German and Bohemian sources (among others utraquist ones). ${ }^{23}$ At the same time, according to Jerzy Pikulik's and my own research they were also used in Cracovian and Wrocławian sources. ${ }^{24}$ 2) A similar case is alleluia Ave virgo sacra Barbara (to the melody of Ave benedicta Maria), which according to Schlager can be found with this text exclusively in the Graduale Wladislai. ${ }^{25}$ However, it appears again in several sources from Cracov and Wrocław too. ${ }^{26}$

Because of the foreign king and because of his strong Bohemian connections and the unfamiliar environment of Buda the hypothesis was plausible from the beginning that the manuscript was ordered by him or for him, namely for his own use at the royal chapel in Buda. ${ }^{27}$ However even these circumstances do not explain the almost heterogeneous and in many respects atypical content of the manuscript. According to a recent hypothesis by Kinga Körmendy, the key place perhaps was not Prague but possibly Olomouc. ${ }^{28}$ According to this hypotheses the manuscript was not ordered by the king but for him on the occasion of the coronation of his son Lewis the second as Bohemian king (1509). The service was celebrated in Prague by Stanislaus Thurzó, bishop of Olmütz,

mation and Religious Practice, Vol. 5. Part 2. Papers from the Fifth International Symposium on The Bohemian Reformation and Religious Practice held at Vila Lanna, Prague 19-22 June 2002. Zdeněk V. David - David R. Holeton (eds.). Praha: Academy of Sciences of the Czech Republic, Main Library, 2005, pp. 316-317.

20 A-Wn Mus. Hs. 15501; CZ-HKm II A 6.

21 CZ-MBm 21691.

22 Kraków, Archiwum i Biblioteka Krakowskiej Kapituły Katedralnej, Ms. 45, f 162v.

23 SCHLAGER, op. cit., pp. 539, 813 and 435, 768.

24 PIKULIK, op. cit., pp. 279, 251.

25 SCHLAGER, op. cit., pp. 46, 587.

26 PIKULIK, op. cit., pp. 115-116.

27 Cf. fnn. 2, 4.

28 KÖRMENDY, op. cit., p. 119-120. 
member of a famous and rich family, who had strong connections with Vladislaus and the members of his Bohemian cancellery in Buda. Consequently the commissioner could have been the bishop or his family and the production of the book was controlled and directed from Olmütz, which had many connections not only with Prague but with Silesia and Cracov and Buda. Although the liturgy of Olmütz was largely based on that of Prague, it had some recognizable special characteristics. So if the new hyphotesis is true, we should find significant concordances between the Graduale Wladislai and the mass sources from Olomouc. Unfortunately the comparison is disappointing. While for example, there are some resemblance in the alleluia series of Paschal weekdays and Sundays, there are significant differences in the two Penthecostal series. Again, it seems as if the compiler of the manuscript would have combined characteristics of several uses, including Prague, Olomouc, Esztergom, Cracov and Wrocław.

Somewhat curiously these uncertainties were partly maintained during the later "unofficial" (or unknown) history of the manuscript. We find many later additions and interventions in the manuscript, which in some cases clarify what liturgical custom the user preferred, but on the whole maintain the intercultural character of the manuscript showing it as a meeting point of several influences of a rite-independent milieu. It is enough to survey the additions to see how many types they represent as to both their content and way of writing. Some of the additions may have been made still at Buda (by unknown scribes), some of them in Trnava, where the codex was escaped from the Turkish invasion and was used in the Strigonian Cathedral resided temporarily there at that time. On f 291-291v we find an introit and a tract for Corpus Christi (Facsimile 4-5), while the former was written with a rustic Messine-Gothic notation by an untrained hand, the tract is notated with cursive Hungarian neumes. In the Kyriale section in several times the later user obviously wanted to take Strigonian characteristics into effect. For example, on f 271 two marginalia change the original De martiribus function of a Kyrie and a Gloria to De apostolis and In Adventu respectively (Facsimile 6). The explanation is the following: in Hungarian sources 1) the two melodies were never used in the same formula and, 2), neither of them had the function of De martiribus. The special Hungarian function for the kyrie was De apostolis and the gloria was frequently used in the mass of BMV in Adventu.

My last two examples show that in the intercultural milieu where the manuscript was used, the added component and the notation used for them sometimes confront each other. On f 10 en empty space was left after the credo melody, where later an alleluia was inserted (Facsimile 7). Alleluia Ab arce siderea is a versified and troped piece, which was disseminated only in a small Central Europen circle. Although according to Schlager it can only be found in Prague sources, actually it was used in Poland as well and to a limited extent in Hungary (even if not in the central Strigonian sources). ${ }^{29}$ In any case, the piece again belongs to the international and "trendy" repertory of the age. What is surprising, however, is that it was notated with the so-called mixed Hungarian-Messine-Gothic notation, which was used exclusively by notators having Hungarian schooling.

29 SCHLAGER, op. cit., pp. 5, 577. But cf. KISS, op. cit., pp. 321-322. 
The last example represents the most contradictory example in the manuscript. On the last and empty page an alleluia was added for Trinity Sunday (Facsimile 8). The late insertion was made with a humanistic text writing and - somewhat surprisingly - with a cursive version of the Bohemian notation. The notator obviously wanted to imitate the basic script of the manuscript in an amateur way. All the more surprising is that the careful Bohemian notation was used to put down a specifically Hungarian piece, namely the alleluia Honor virtus, which replaced the generally used alleluia for the feast (Benedictus es Domine), but exclusively in Strigonian sources. So, we are faced here with the insertion of a typically Hungarian melody by using the typically Bohemian notation, for which phenomenon I don't know any other example.

So the mystery of the Graduale Wladislai remains unsolved, but the analysis of it and the effort to find answers to its controversial features help understand better that late medieval milieu in which there was great mobility, pieces were wandering between different areas and sources, centres and traditions influenced each other in a complex and fruitful way.

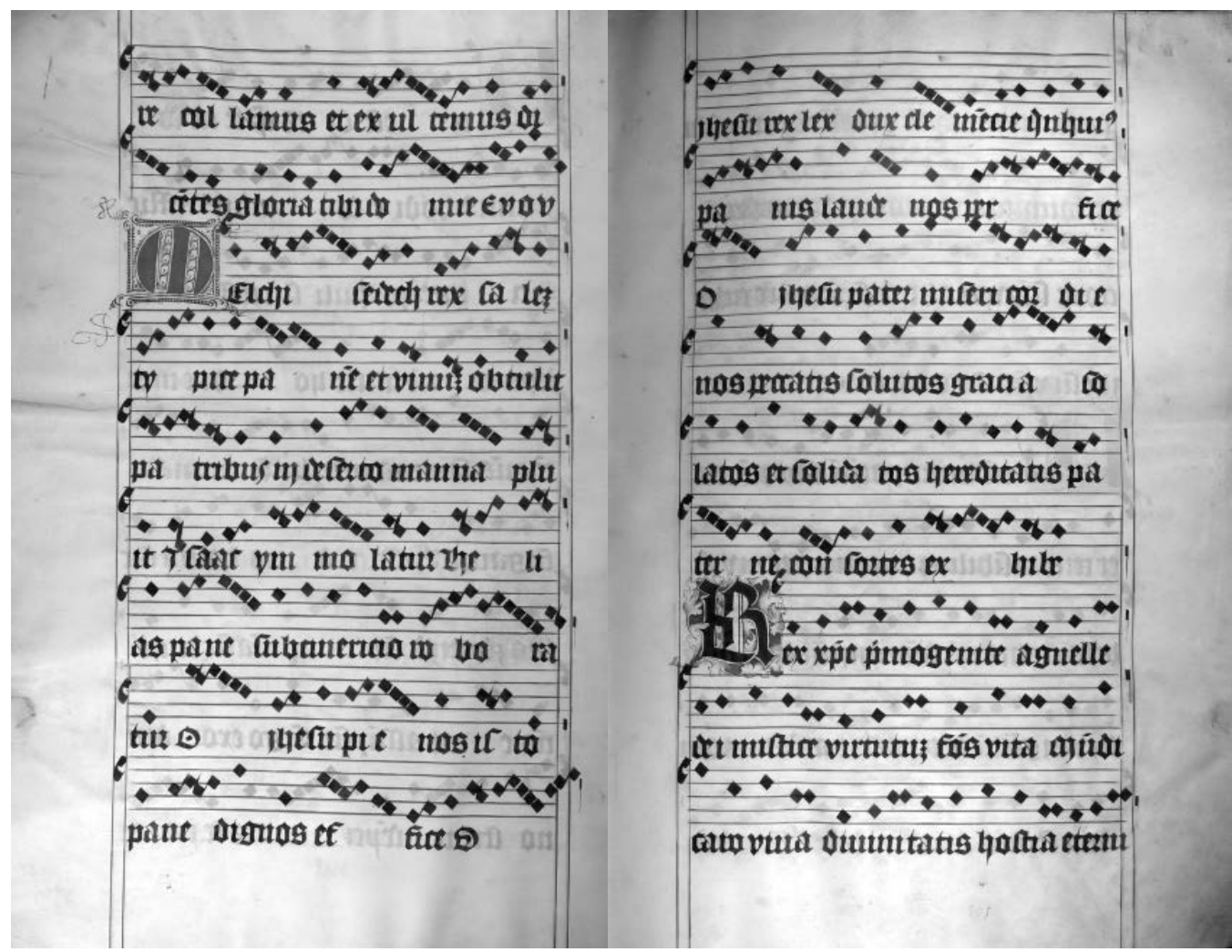

Facsimile 2-3. H-Efkö Mss. I. 3, f 7v-8. 
Mixing Local and Regional, Traditional and Non-traditional Elements...

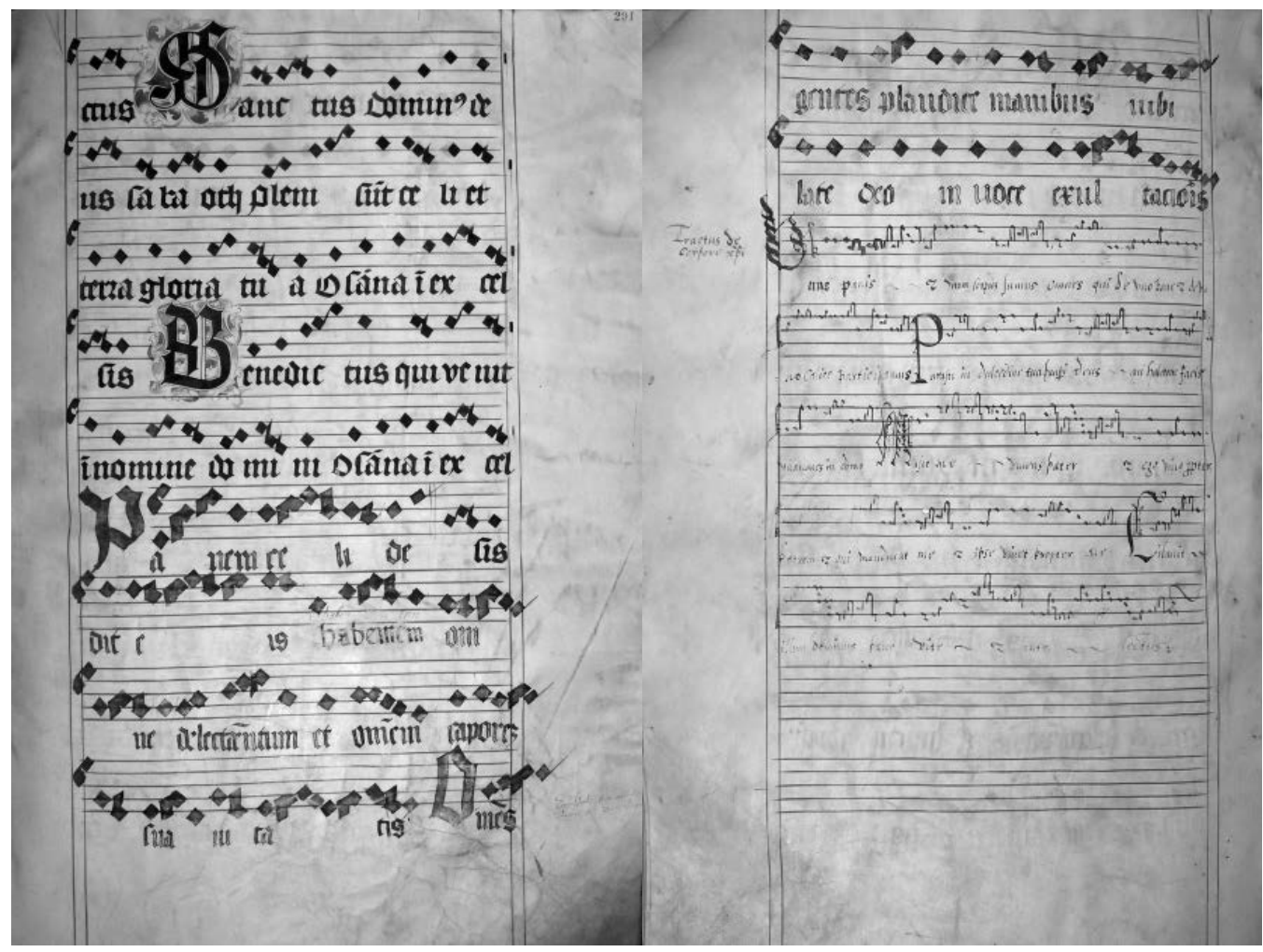

Facsimile 4-5. H-Efkö Mss. I. 3, f 291-291v.

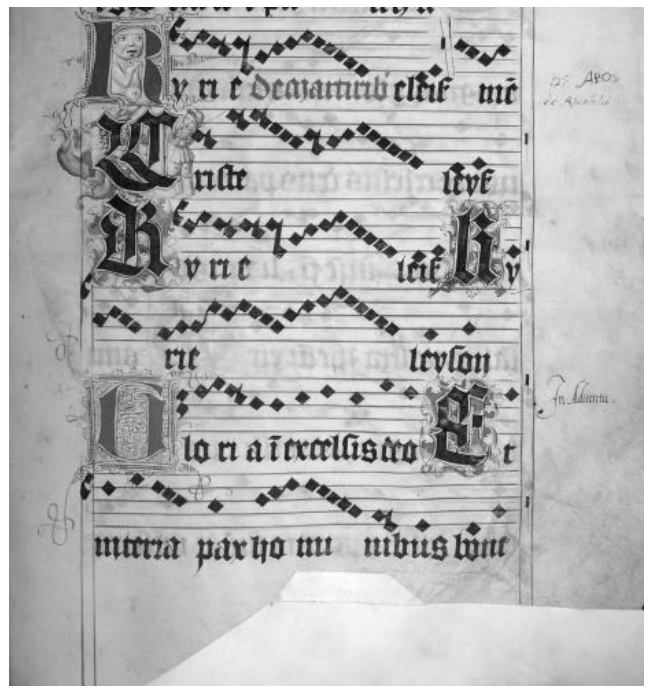

Facsimile 6. H-Efkö Mss. I. 3, f 271.

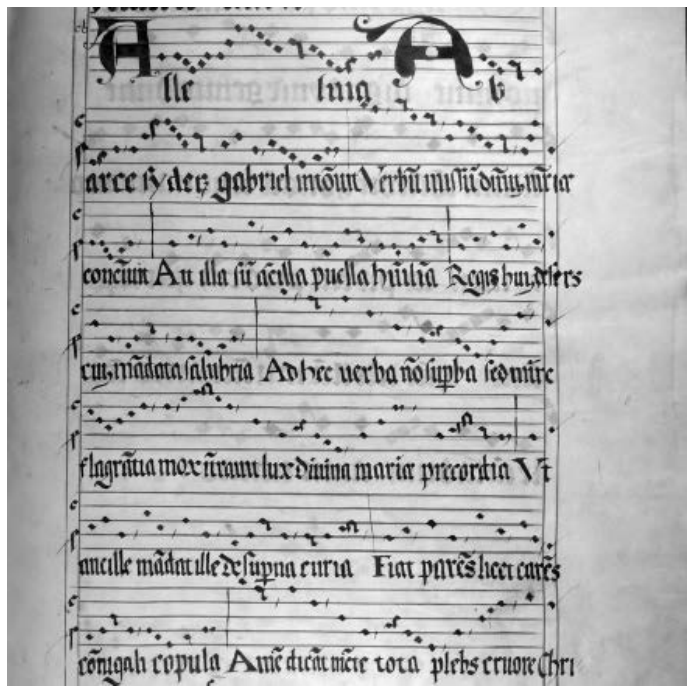

Facsimile 7. H-Efkö Mss. I. 3, f 10. 


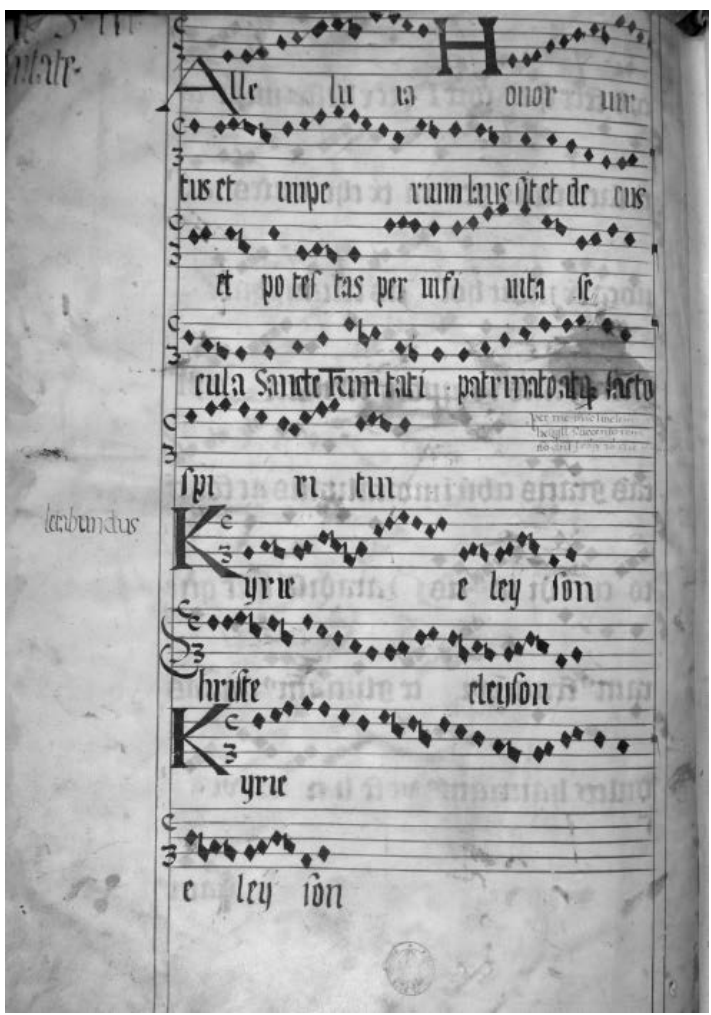

Facsimile 8. H-Efkö Mss. I. 3, f 280.

\section{Bibliography}

BERKOVITS, Ilona. Az esztergomi Ulászló-graduale. Magyar Könyuszemle, 1941, vol. 65, pp.

CSONTOSI, János. Könyvkiállitási emlék. Budapest: Országos Magyar Iparművészeti Múzeum, 1882.

DREVES, Guido Maria (ed.). Analecta Hymnica Medii Aevi, vol. 9. Leipzig: O. R. Reisland, 1890.

GRAHAM, Barry Frederic Hunter. Bohemian and Moravian Graduals 1420-1620. Turnhout: Brepols, 2006.

IZBICZKI, Bartosz. Graduat tyniecki ms. b. s. I w świetle tradycji europejskiej i polskiej. Warsawa: Uniwersytet Kardynała Stefana Wyszyńskiego, 2006. (PhD diss.).

KISS, Gábor. Az Ulászló-graduále utóélete az újabb kutatások fényében [The Later History of the Graduale Wladislai in the Light of Recent Studies]. Magyar Egyházzene, 2013, vol. 20, pp. 315-322.

KÖRMENDY, Kinga. Ulászló-graduále: kérdések és lehetséges válaszok [The Ladislaus Gradual:

Questions and Possible Explanations]. Ars Hungarica, 2013, vol. 39, no. 1, pp. 114-122. 
PIKULIK, Jerzy. Spiewy Alleluia de Sanctis w polskich rekopisach przedtrydenckich: Studium muzykologiczne. Warsawa: Wydawnictwa Akademii Teologii Katolickiej, 1995.

RADÓ, D. Polycarpus OSB. Libri liturgici manuscripti bibliothecarum Hungariae et limitropharum regionum. Budapest: Akadémiai Kiadó, 1973.

SCHLAGER, Karlheinz. Alleluia-Melodien. Kassel-Basel: Bärenreiter, 1987.

SZENDREI, Janka. A magyar középkor hangjegyes forrásai [Notated Manuscripts of the Hungarian Middle Ages]. Budapest: MTA Zenetudományi intézet, 1981.

SZENDREI, Janka. A Szent István alleluják dallamai [The melodies of the alleluias for St. Stephen]. Zenetudományi Dolgozatok, 1989, pp. 7-19.

VLHOVÁ-WÖRNER, Hana. Bohemian Utraquists‘ Repertory of Proper Tropes. In: The Bohemian Reformation and Religious Practice, Vol. 5. Part 2. Papers from the Fifth International Symposium on The Bohemian Reformation and Religious Practice held at Vila Lanna, Prague 19-22 June 2002. Zdeněk V. David - David R. Holeton (eds.). Praha: Academy of Sciences of the Czech Republic, Main Library, 2005, pp. 313-327. 